The Philosophical Journal of Conflict and Violence

Vol. I, Issue 2/2017

(C) The Authors, 2017

Available online at http://trivent-publishing.eu/

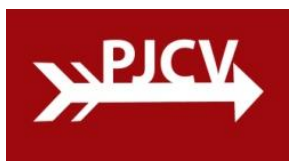

\title{
INTRODUCTION TO INTERVIEWS
}

The three interviews with René Girard introduced in this issue of our journal have been available in French for some time now. They cover the period of six years (2002-2008) during which Girard published his final books (Sacrifice, Evolution and Conversion, Christianity, Truth and Weakening Faith, Battling to the End).

The first interview, "What are our Values Worth?", appeared initially in the French newspaper La Croix on December 13, 2002. Here Laurent d'Ersu and Robert Migliorini question Girard on the problematic status of Western values after 9/11 and their uncertain prospects in the age of globalization. During the interview, Girard discusses the hidden motivations of jihadism, commenting on George W. Bush's "War on Terror". He also criticizes what he perceives as common Western misunderstandings of Judeo-Christian anthropology.

The second interview, "Facing the Devil's Test: The Truth According to René Girard", was published in the French Catholic Magazine Certitudes in 2005. In an extended dialogue with Laurent Linneuil and the Abbé de Tanoüarn, Girard addresses a somewhat broader range of issues. His interviewers are primarily interested in theological aspects of Mimetic Theory. They ask Girard to define Satan, to discuss the filiation of Judaism and Christianity, to clarify the status of original sin in his anthropology of human beginnings as well as his attitude towards Augustine. However, Girard also treats a number of other subjects he rarely if ever discussed, including his opinion of Philippe Muray's concept of "post-history", the role of mimetic desire in Voltaire's Candide, the depiction of archaic sacrifice in Flaubert's Salammbô, and the difficulties of interpreting the Quran. It is worth mentioning that the interview was published in a special issue of the magazine entitled: "Laïcité: a French Ideology" ("Laïcité: cette idéologie Française"). At the time, France was celebrating the centenary of its 1905 law on the separation of church and state. Issues related to the law and the correct understanding of French Laïcité dominated books, articles, and television debates. In this political atmosphere questions about the status of Christianity in France weighed heavily. Although the historical context is never explicitly mentioned during the interview, a number of questions and remarks relate directly to it.

In September 2008 Pierre Farge interviewed Girard at Stanford University. The transcript was later published in the French online journal Contrepoints in November of 2015. In a brief exchange with Farge, Girard summarizes salient features of his apocalyptic outlook developed at length in Achever Clausewitz (Battling to the End), laying special emphasis on the uniqueness of Christianity vis-à-vis ancient religions. In so doing he concisely relates his theories to the epoch-making 9/11 terrorist attacks and the 2008 subprime mortgage crisis. 
These interviews demonstrate that Girard's interests went well beyond introducing his theories to a wider audience. He frequently brought his interpretive powers to bear on news events and current affairs, taking on subjects he does not discuss in the main body of his work. The interviews collected here mirror Girard's complex attitude toward modernity. If modern Western societies are alone able to take "a detached interest in victims" (Certitudes, 2005), they also exploit the Christian revelation to their own advantage (La Croix, 2002), thoughtlessly accelerating the escalation to extremes on the international scene. In Girard's view the modern predicament is neither a state of pure decadence nor the heaven of human progress some have imagined. The apocalyptic temper of his thought is accordingly nuanced: the global revelation of human violence is lit by a glimmer of hope. As Girard puts it in an interview with Robert Doran from 2007:

Jacques Maritain said that there is more good and more bad in the world all the time. I think this is an excellent formula. In other words, the world is both more Christian and less Christian, constantly. But it is fundamentally disorganized by Christianity. ${ }^{1}$

We hope our translations have captured the spirit and liveliness of these interviews. A few footnotes were added to Girard's interview for Certitudes (2005) to provide needed context for some remarks and ease the reading of certain passages. Misprints in the French transcripts were corrected for all translations. In interviews Girard frequently quotes biblical excerpts by memory and in an allusive way. For each excerpt, we have chosen authorized English translations (shown in square brackets) that come closest to the words and meanings in French. To enrich the readings, we have included the biblical verses in their entirety. Text excerpts which are not directly quoted by Girard appear in square brackets.

Andreas Wilmes \& David Dawson

\section{Acknowledgements}

The Philosophical Journal of Conflict and Violence would like to thank the editorial boards of La Croix, Certitudes and Contrepoints for the translation rights to these interviews. The translators would also like to express their gratitude to Pierre Farge who read and revised the first translation drafts of René Girard's interview for Contrepoints.

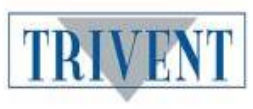

The PJCV Journal is published by Trivent Publishing.

\footnotetext{
${ }^{1}$ René Girard, Robert Doran, “Apocalyptic Thinking after 9/11”, SubStance 37/1 (2008): 27.
} 